\title{
Deoxyribonucleic Acid Homology and Taxonomy of the Genus Bacillus
}

\author{
TATSUJI SEKI, CHI-KWAN CHUNG, $\dagger$ HIDETADA MIKAMI, †† AND YASUJI OSHIMA
}

Department of Fermentation Technology, Osaka University, Yamadakami, Suita-shi, Osaka 565, Japan

\begin{abstract}
The taxonomic relationships among 56 strains of 16 species of the genus Bacillus were studied by deoxyribonucleic acid (DNA)-DNA hybridization. In general, no significant DNA homology was detected between two strains of different species, except for a group of species consisting of $B$. subtilis, $B$. amyloliquefaciens, $B$. licheniformis, and $B$. pumilus and for another group of species including $B$. cereus and $B$. thuringiensis. Species of the former group were related, but they were independent of each other as their DNA homologies were $19 \%$ or less. The DNA homology indexes of three strains of $B$. thuringiensis to $B$. cereus T, so far tested, showed high DNA homologies (54 to $80 \%$ ). This fact indicates that $B$. thuringiensis should be an identical species to $B$. cereus. The intraspecific DNA homology indexes of 16 strains of $B$. pumilus were $51 \%$ or more to strain IFO 12092 as the standard, and those of 10 strains of $B$. coagulans were 76 to $113 \%$ to strain ATCC 7050 as the standard. Thus, the species identification of $B$. pumilus and $B$. coagulans by the conventional taxonomic method was well in accord with the DNA homology data. On the other hand, significant heterogeneities were suggested among the strains of $B$. circulans and among those of $B$. sphaericus by the DNA homology data of the three and five strains so far tested, respectively. Although $B$. lentus was described to be closely related to $B$. firmus in Bergey's Manual (8th ed., 1974), the interspecific DNA homology index between these two species was $3 \%$. It was concluded that these two species are independent.
\end{abstract}

According to the description by Smith et al. (13), a wide variety of Bacillus species were divided into three groups with respect to their sporangium and spore characteristics. The species belonging to group 1 form indefinitely swollen sporangia, whereas the other species showing swollen sporangia are included in the second and third groups. Of the latter two groups, group 3 consists of species forming characteristic spherical spores. In a previous communication (12), the taxonomic relationships among 52 test strains of 8 species of Bacillus belonging to group 1, except for one strain of $B$. brevis, were studied by deoxyribonucleic acid (DNA)-DNA hybridization and by the transformability of the auxotrophic and antibiotic resistance genetic markers. Results of species identification by DNA-DNA hybridization data for $B$. licheniformis and $B$. megaterium showed good agreement with those obtained by the conventional taxonomic method according to Bergey's Manual, 8 th ed. (5), and by the methods of Gordon et al. (6) and Smith et al. (13). However, the strains of

† Present address: Chong Kun Dang Corporation, no. 410 Shin Do Rim-Dong, Young Deung Po-ku, Seoul, Republic of Korea.

†† Present address: Research Laboratory, Toyama Chemical Co., Ltd., 2-4-1 Shimo-okui, Toyama 930, Japan.
B. subtilis identified by the conventional taxonomic method were divided into two groups, in which $B$. subtilis 168 and $B$. amyloliquefaciens KA-63 are representative of each group, by DNA-DNA hybridization data and by transformation ability. This communication is a followup to the previous one (12) and deals with the taxonomic relationships between various additional species of Bacillus distributed in groups 1,2 , and 3 by the DNA-DNA hybridization technique.

\section{MATERIALS AND METHODS}

Strains. The strains used are listed in Table 1. Fifty-two strains were obtained from authentic sources and six strains of $B$. coagulans were newly isolated from soil. Escherichia coli K-12 was also used as a test strain. The taxonomic significance of the test strains was critically examined according to Bergey's Manual, 8 th ed. (5), by the method of Gordon et al. (6). All strains, except for 11 strains of $B$. coagulans, were stored at room temperature on Difco nutrient agar slants containing potato extract (Difco, $0.5 \%$ ) and supplemented with $200 \mu \mathrm{g}$ of thymine per $\mathrm{ml}$ if necessary. The 11 strains of $B$. coagulans were stored at $4^{\circ} \mathrm{C}$ on PGY agar slants composed of polypeptone (Daigo Eiyo, $1 \%$ ), glucose (1\%), yeast extract (Oriental Yeast, $1 \%$ ) (pH 7.0), and agar (2\%) supplemented with $200 \mu \mathrm{g}$ of thymine per $\mathrm{ml}$ if necessary. Five thymine 
TABLE 1. List of strains used

\begin{tabular}{|c|c|}
\hline Strain & Remarks $^{a}$ \\
\hline \multicolumn{2}{|l|}{ B. subtilis } \\
\hline $168 \operatorname{trp} C$ & $\Leftarrow \mathrm{S}$. Yuki $\Longleftarrow$ J. L. Farmer and F. Rothman \\
\hline $168 \operatorname{trp} C$ thy $A B$ & $\Leftarrow \mathrm{S}$. Yuki $\Leftarrow$ J. L. Farmer and F. Rothman \\
\hline B. subtilis subsp. niger OUT 8111 & $\begin{array}{l}=\text { IFO } 3108 \Longleftarrow \text { Research Laboratories, Takeda Chemical } \\
\text { Industries Ltd., Osaka, Japan }\end{array}$ \\
\hline B. amyloliquefaciens ${ }^{b}$ KA- 63 & $\begin{array}{l}\text { OUT stock culture } \Longleftarrow \mathrm{G} \text {. Terui (Department of Fermentation } \\
\text { Technology, Osaka University, Suita, Japan) }\end{array}$ \\
\hline B. licheniformis IFO 12107 & $\Leftarrow$ ATCC $9945 \mathrm{a} \Leftarrow \mathrm{C} . \mathrm{B}$. Thorne, CD-2 \\
\hline \multicolumn{2}{|l|}{ B. pumilus } \\
\hline IFO 3813 & $\Leftarrow$ NCTC 8241, strain Mill Hill (ATCC 14884) \\
\hline IFO 12086 & $\Leftarrow \mathrm{NCIB} 2595 \Longleftarrow \mathrm{NCTC} \Leftarrow \mathrm{ATCC} 4520 \Longleftarrow \mathrm{W} . \mathrm{W}$. Ford, 9 \\
\hline IFO 12087 & $\Leftarrow$ NCIB $7576 \Longleftarrow$ NCTC $7576 \Longleftarrow T$. Gibson, 33 \\
\hline IFO 12088 & $\Leftarrow$ NCIB $8081 \Leftarrow$ ATCC $6632 \Leftarrow$ N. R. Smith, 247 \\
\hline IFO 12089 & $\Leftarrow$ NCIB $8600 \Leftarrow \mathrm{CDA} 658$ \\
\hline IFO 12090 & $\begin{array}{l}\Leftarrow \text { NCIB } 8738 \Leftarrow \text { A. T. Fuller (Medical Research Council, } \\
\text { London) }\end{array}$ \\
\hline IFO 12092 & $\Leftarrow$ NCIB $9369 \Longleftarrow$ ATCC $7061 \Longleftarrow$ N. R. Smith, 272 \\
\hline IFO 12093 & 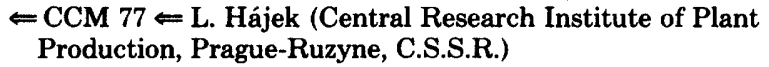 \\
\hline IFO 12094 & $\begin{array}{l}\text { CCM } 340=0 \text {. Mráz (Department of Microbiology, Fac- } \\
\text { ulty of Veterinary, Medical School, Brno University, } \\
\text { C.S.S.R.) }\end{array}$ \\
\hline IFO 12097 & $\begin{array}{l}\Leftarrow \text { CCM } 386 \Leftarrow \text { M. Kocur (University of J. E. Purkyne, Brno, } \\
\text { C.S.S.R.) }\end{array}$ \\
\hline IFO 12099 & $\begin{array}{l}\Leftarrow \mathrm{CCM} 615 \Leftarrow \mathrm{M} . \text { Kocur (University of J. E. Purkyne, Brno, } \\
\text { C.S.S.R.) }\end{array}$ \\
\hline IFO 12100 & $\begin{aligned} \Leftarrow \mathrm{CCM} 1697 \Longleftarrow \mathrm{G} . \text { Ivánovics (Institute of Microbiology, } \\
\text { Medical University, Szeged, Hungary) } \Longleftarrow \mathrm{N} . \mathrm{R} \text {. Smith, 736 }\end{aligned}$ \\
\hline IFO 12101 & $\begin{array}{l}=\mathrm{CCM} 1725=\mathrm{G} \text {. Ivánovics (Institute of Microbiology, } \\
\text { Medical University, Szeged, Hungary) }\end{array}$ \\
\hline IFO 12102 & $\Leftarrow \mathrm{CCM} 2218 \Leftarrow \mathrm{NCIB} 8982$ \\
\hline IFO 12110 & $\Leftarrow$ NRRL B-1489 $\Longleftarrow$ N. R. Smith, 236 (ATCC 6631) \\
\hline IFO 12111 & $\Leftarrow$ NRRL B-1875 $\Leftarrow$ N. R. Smith, T-2003 \\
\hline \multicolumn{2}{|l|}{ B. firmus } \\
\hline ATCC $14575^{* c}$ & $\begin{array}{l}\Leftarrow \text { R. E. Gordon } \Leftarrow \text { N. R. Smith, } 613 \Longleftarrow \text { J. R. Porter } \Leftarrow \text { G. } \\
\text { Bredeman } \Leftarrow \text { W. Werner }\end{array}$ \\
\hline IFO 3330 & $\underset{\text { Bredeman, A }}{=\text { ATCC } 8247 \Leftarrow \text { N. R. Smith, } 854 \Leftarrow \text { J. R. Porter } \Leftarrow \text { G. }}$ \\
\hline B. lentus ATCC $10840^{*}$ & $\Leftarrow$ N. R. Smith, $670 \Longleftarrow T$. Gibson, 165 \\
\hline \multicolumn{2}{|l|}{ B. coagulans } \\
\hline $\begin{array}{l}\text { ATCC } 7050^{*} \\
\text { IFO } 3557\end{array}$ & $\begin{array}{l}\Longleftarrow \text { N. R. Smith, } 609 \Longleftarrow \text { J. R. Porter } \Longleftarrow \text { B. W. Hammer } \\
\Longleftarrow \text { T. Harada (Institute of Scientific and Industrial Research, } \\
\text { Osaka University, Suita, Japan) }\end{array}$ \\
\hline IFO 3886 & $\begin{array}{l}\text { O. Nakayama, P22 (Research Institute of Fermentation, } \\
\text { Yamanashi University, Kofu, Japan) }\end{array}$ \\
\hline IFO 3887 & $\begin{array}{l}=0 . \text { Nakayama, A22 (Research Institute of Fermentation, } \\
\text { Yamanashi University, Kofu, Japan) }\end{array}$ \\
\hline IFO 12583 & $\Longleftarrow \mathrm{IAM} 1115$ \\
\hline $\mathrm{C1}$ & Isolated from soil \\
\hline $\mathrm{C} 2$ & Isolated from soil \\
\hline C3 & Isolated from soil \\
\hline $\mathrm{C} 4$ & Isolated from soil \\
\hline C5 & Isolated from soil \\
\hline C6 & Isolated from soil \\
\hline \multicolumn{2}{|l|}{ B. megaterium IAM 1030} \\
\hline \multicolumn{2}{|l|}{ B. cereus } \\
\hline $\mathbf{T}$ & $\Longleftarrow$ H. O. Halvorson \\
\hline T thy & $\Longleftarrow$ H. O. Halvorson \\
\hline ATCC $14579^{*}$ & $\Leftarrow$ R. E. Gordon $\Leftarrow$ T. Gibson, $971 \Leftarrow$ W. W. Ford, 13 \\
\hline IAM 1229 & \\
\hline ATCC 13824 & $\Leftarrow$ NCIB 2600 (B. cereus subsp. fluorescens) $\Longleftarrow$ W. W. Ford \\
\hline
\end{tabular}


TABLE 1 -ContinUeD

\begin{tabular}{|c|c|}
\hline Strain & Remarks $^{a}$ \\
\hline \multicolumn{2}{|l|}{ B. thuringiensis } \\
\hline subsp. aizawai & $\begin{array}{l}\Leftarrow \mathrm{K} \text {. Aizawa (Institute of Biological Control, Faculty of } \\
\text { Agriculture, Kyushu University, Fukuoka, Japan), sero- } \\
\text { type 1 }\end{array}$ \\
\hline subsp. kurstaki & $\begin{array}{l}\Leftarrow \mathrm{K} \text {. Aizawa (Institute of Biological Control, Faculty of } \\
\text { Agriculture, Kyushu University, Fukuoka, Japan), sero- } \\
\text { type 3a, 3b }\end{array}$ \\
\hline subsp. thuringiensis & $\begin{array}{l}\Leftarrow \mathrm{K} \text {. Aizawa (Institute of Biological Control, Faculty of } \\
\text { Agriculture, Kyushu University, Fukuoka, Japan), sero- } \\
\text { type } 7\end{array}$ \\
\hline \multicolumn{2}{|l|}{ B. circulans } \\
\hline ATCC 4513* & $\Leftarrow \mathrm{W} . \mathrm{W}$. Ford, 26 \\
\hline IFO 3329 & $\Leftarrow$ ATCC $9966 \Longleftarrow$ FDA PCI-221 \\
\hline IFO 3342 & $\begin{array}{l}=\text { Instituto de Microbiologia Agricola, Buenos Aires, Argen- } \\
\text { tine, B-3-6 } 6 \text { ATCC } 7049 \Longleftarrow \text { N. R. Smith, } 358 \Longleftarrow \text { W. W. } \\
\text { Ford, } 26\end{array}$ \\
\hline B. laterosporus ATCC $64^{*}$ & $\underset{\text { Laubach }}{=\mathrm{AMC}} 797 \Leftarrow \mathrm{AMNH} 797 \Leftarrow$ W. W. Ford, $29 \Leftarrow \mathrm{C} . \mathrm{A}$. \\
\hline B. polymyxa ATCC $842^{*}$ & $\Leftarrow$ A. J. Kluyver (N. R. Smith, 1105) \\
\hline \multicolumn{2}{|l|}{ B. brevis } \\
\hline ATCC $824 b^{\circ}$ & $\begin{array}{l}\Leftarrow \text { N. R. Smith, } 604 \Leftarrow J . \text { R. Porter } \Leftarrow N C T C 2611 \Leftarrow \text { W. W. } \\
\text { Ford, 27B }\end{array}$ \\
\hline IFO 3864 & $\Leftarrow$ ATCC $9999 \Longleftarrow$ NCTC $7096 \Longleftarrow$ R. L. M. Synge \\
\hline IFO 12333 & $\Leftarrow$ ATCC $8186 \Leftarrow$ R. E. Gordon \\
\hline \multicolumn{2}{|l|}{ B. sphaericus } \\
\hline ATCC $14577^{*}$ & $\begin{array}{l}\Leftarrow \mathrm{R} . \mathrm{E} \text {. Gordon } \Longleftarrow \mathrm{T} \text {. Gibson, } 1013 \Leftarrow \mathrm{Král} \text { collection (Mar- } \\
\text { burg strain) } \Longleftarrow \mathrm{M} \text {. Wund } \Longleftarrow \mathrm{E} \text {. Neide }\end{array}$ \\
\hline IFO 3341 & $\Longleftarrow \mathrm{IMAB} B-3-5 \Longleftarrow \mathrm{N} . \mathrm{R}$. Smith, 344 \\
\hline IFO 3525 & $\Leftarrow$ ATCC $10208 \Longleftarrow \mathbf{N}$. R. Smith, 966 \\
\hline IFO 3526 & $\Leftarrow$ ATCC $4525 \Leftarrow$ W. W. Ford, 25 (N. R. Smith, 348) \\
\hline IFO 3528 & $\Leftarrow$ ATCC $7055 \Longleftarrow$ N. R. Smith, 350 \\
\hline $\begin{array}{l}\text { B. pantothenticus ATCC } 14576^{*} \\
\text { Escherichia coli K-12 }\end{array}$ & $\begin{array}{l}\Leftarrow \text { R. E. Gordon } \Leftarrow \text { N. R. Smith, } 1321 \Leftarrow \text { H. Proom, CN3028 } \\
\text { Our stock culture }\end{array}$ \\
\hline
\end{tabular}

${ }^{a}$ Abbreviations of the authentic culture collections were as follows: AMC, Walter Reed Army Medical Center, Washington, D.C.; AMNH, American Museum of National History, New York, N.Y.; ATCC, American Type Culture Collection, Rockville, Md.; CCM, Czechoslovak Collection of Microorganisms, University of J. E. Purkyne, Brno, Czechoslovakia; CDA, Canadian Department of Agriculture, Ottawa, Canada; FDA, Food and Drug Administration, Washington, D.C.; IAM, Institute of Applied Microbiology, University of Tokyo, Tokyo, Japan; IFO, Institute for Fermentation, Osaka, Japan; NCIB, National Collection of Industrial Bacteria, Torry Research Station, Aberdeen, Scotland; NCTC, National Collection of Type Cultures, Central Public Health Laboratory, London, England; NRRL, Northern Utilization Research and Development Division, U.S. Department of Agriculture, Peoria, Ill.; OUT, Department of Fermentation Technology, Osaka University, Suita, Japan.

${ }^{b}$ This strain was designated as $B$. subtilis KA-63 in a previous communication (12).

c The type strain or neotype strain in Bergey's Manual, 8th ed. (4), is marked with an asterisk $\left({ }^{*}\right)$.

auxotrophic mutants were isolated from $B$. pumilus IFO $12092, B$. firmus ATCC $14575, B$. coagulans ATCC $7050, B$. circulans ATCC 4513 , and $B$. sphaericus ATCC 14577 by the enrichment method, using trimethoprim (Sigma) in Spizizen minimal medium (15) containing 200 or $2 \mu \mathrm{g}$ of thymine per $\mathrm{ml}$ as described previously (12). For the isolation and cultivation of thymine mutants of $B$. pumilus IFO 12092 , $B$. firmus ATCC 14575, B. coagulans ATCC 7050, and $B$. circulans ATCC 4513, the minimal medium was further supplemented with $1 \mu \mathrm{g}$ of biotin per $\mathrm{ml} ; 1 \mu \mathrm{g}$ of biotin and $10 \mu \mathrm{g}$ of thiamine per ml; $1 \mu \mathrm{g}$ of biotin, $1 \mu \mathrm{g}$ of thiamine, and $10 \mu \mathrm{g}$ of nicotinic acid per $\mathrm{ml}$; or $1 \mu \mathrm{g}$ of thiamine and $10 \mu \mathrm{g}$ of nicotinic acid per $\mathrm{ml}$, respectively, whereas $B$. sphaericus ATCC 14577 could grow on the enrichment medium without addition of vitamins.
Media and growth conditions for cells in the preparation of DNA. For the cultivation of $B$. brevis ATCC 8246 and B. polymyxa ATCC 842, PGY medium without agar was used. For cultivation of 3 strains of $B$. circulans and 11 strains of $B$. coagulans, PGY medium supplemented with $1 \%$ Casamino Acids (Difco, vitamin-free) was used. For cultivation of two strains of $B$. firmus and $B$. pantothenticus ATCC 14576 , brain heart infusion (Difco, 3.7\%) medium supplemented with $1 \%$ Casamino Acids (pH 7.0) was used. All the other strains were cultivated in nutrient broth (Difco, 1.6\%). The cultivation temperature was $37^{\circ} \mathrm{C}$ for all strains except $B$. coagulans, for which it was $48^{\circ} \mathrm{C}$.

For the preparation of $\left[{ }^{3} \mathrm{H}\right] \mathrm{DNA}$, cells of the thymine-requiring mutants were cultivated in Spizizen minimal medium (15) containing $1 \%$ Casamino Acids 
and $2 \mu \mathrm{g}$ of $\left[\right.$ methyl $\left.-{ }^{3} \mathrm{H}\right]$ thymine per $\mathrm{ml}(1.25 \mu \mathrm{Ci} / \mu \mathrm{g}$; The Radiochemical Centre Ltd., Amersham, England), and supplemented with $200 \mu \mathrm{g}$ of L-tryptophan per $\mathrm{ml}$ and the vitamins described above, if necessary.

DNA preparation and DNA-DNA hybridization. In general, DNA was extracted and purified by the method of Marmur (11). Since cells of $B$. cereus, $B$. thuringiensis, and $B$. sphaericus did not lyse on treatment with lysozyme and sodium lauryl sulfate, 3 mg of penicillin G (Meiji Seika Co., Ltd.) per ml was added to the cultures at the late logarithmic phase, and cultivation was continued for a further 2 to $3 \mathrm{~h}$. The cells treated with penicillin easily lysed and gave a good yield of DNA upon treatment with lysozyme and sodium lauryl sulfate, combined.

The DNA-DNA hybridization was conducted on a nitrocellulose membrane filter by the method described previously (12). One milliliter of DNA solution containing $25 \mu \mathrm{g}$ of DNA in $1 \times \mathrm{SSC}(\mathrm{SSC}=0.15 \mathrm{M}$ $\mathrm{NaCl}$ plus $0.015 \mathrm{M}$ sodium citrate) was denatured by adding $1 \mathrm{ml}$ of $0.3 \mathrm{M} \mathrm{NaOH}$ solution and allowing it to stand for $10 \mathrm{~min}$ at room temperature; the solution was then neutralized with $1 \mathrm{M} \mathrm{HCl}$. The denatured DNA solution was adjusted to $6 \times$ SSC and passed through a nitrocellulose membrane filter $(25 \mathrm{~mm}$ in diameter, $0.45-\mu \mathrm{m}$ pore size; Sartorius Membranfilter $\mathrm{GmbH}$, Federal Republic of Germany), and the filter fixed with DNA was dried for $2 \mathrm{~h}$ at room temperature and for $2 \mathrm{~h}$ in a vacuum ( $<20$ torr) oven at $80^{\circ} \mathrm{C}$. The DNA-DNA hybridization was performed by gently shaking the DNA disk at $37^{\circ} \mathrm{C}$ for $22.5 \mathrm{~h}$ in a capped small glass vial containing $1 \mathrm{ml}$ of $6 \times \mathrm{SSC}$-formamide (50\%) solution with 0.5 or $1 \mu \mathrm{g}$ of denatured ${ }^{3} \mathrm{H}$-labeled input DNA prepared from an authentic standard strain. The amount of input DNA bound to the disk DNA was estimated by counting the radioactivity of the membrane filter, using a liquid scintillation counter (Beckman model LS-250) as described previously (12).

\section{RESULTS}

Intraspecific DNA homologies in B. pumilus and $B$. coagulans. The DNA homology data were obtained from the reactions between the ${ }^{3} \mathrm{H}$-labeled input DNA prepared from $B$. pumilus IFO 12092 and the unlabeled disk DNAs from the other 15 strains of B. pumilus. It was confirmed by conventional taxonomic studies that these 16 strains are $B$. pumilus as their cell diameters were smaller than $0.9 \mu \mathrm{m}$, and they could neither hydrolyze starch nor reduce $\mathrm{NO}_{3}$ to $\mathrm{NO}_{2}(6)$. Their DNA homology indexes were $51 \%$ or more to the homologous reaction of strain IFO 12092 (Table 2). Lovett and Young (10) made a similar observation that DNA prepared from each of seven strains of $B$. pumilus showed 58 to $99 \%$ homology to that of the reference strain, NRRL B-3275. To determine the DNA homologies of $B$. pumilus with the other species, ${ }^{3} \mathrm{H}$-labeled input DNA prepared from strain IFO 12092 was further tested with the disk DNAs of the other 15 different species (25 strains), and the disk DNAs from strains IFO 12086, IFO 12092, IFO 12094, and IFO 12101 were tested with input DNA from each of the other six species. The results showed significantly lower values ( 1 to $8 \%$ ) of DNA homology than the above intraspecific values (see Table 5), indicating that the 16 strains of $B$. pumilus are of a single species and that the conventional taxonomic criteria are effective for species identification.

To study the DNA homologies between different strains of $B$. coagulans, six strains were newly isolated from soil. Their morphological and physiological characteristics by conventional taxonomic study clearly indicated that the six newly isolated strains were $B$. coagulans, as were the five authentic strains. The DNA homology indexes of the 10 strains of $B$. coagulans to strain ATCC 7050 as the standard were $76 \%$ or more (Table 3), whereas no significant DNA

TABLE 2. Intraspecific DNA homology among the strains of B. pumilus ${ }^{a}$

\begin{tabular}{cc}
\hline Strain & $\begin{array}{c}\text { Homology to strain } \\
\text { IFO 12092 }(\%)\end{array}$ \\
\hline IFO 3813 & 78 \\
IFO 12086 & 80 \\
IFO 12087 & 68 \\
IFO 12088 & 81 \\
IFO 12089 & 82 \\
IFO 12090 & 58 \\
IFO 12092 & 100 \\
IFO 12093 & 78 \\
IFO 12094 & 97 \\
IFO 12097 & 74 \\
IFO 12099 & 57 \\
IFO 12100 & 63 \\
IFO 12101 & 76 \\
IFO 12102 & 92 \\
IFO 12110 & 51 \\
IFO 12111 & 76 \\
\hline
\end{tabular}

${ }^{a}$ The homology index is expressed as percentage of input DNA bound to a certain disk DNA relative to the homologous reaction.

TABLE 3. Intraspecific DNA homology among the strains of B. coagulans ${ }^{a}$

\begin{tabular}{lc}
\hline Strain & $\begin{array}{c}\text { Homology to strain } \\
\text { ATCC } 7050(\%)\end{array}$ \\
\hline ATCC 7050 & 100 \\
IFO 3557 & 98 \\
IFO 3886 & 90 \\
IFO 3887 & 113 \\
IFO 12583 & 99 \\
C1 & 95 \\
C2 & 76 \\
C3 & 86 \\
C4 & 89 \\
C5 & 91 \\
C6 & 98 \\
\hline
\end{tabular}

${ }^{a}$ The homology index is expressed as percentage of input DNA bound to a certain disk DNA relative to the homologous reaction. 
homology was observed when the reference strain of $B$. coagulans, ATCC 7050, was tested against the other species (see Table 5). Thus, all 11 strains, 6 newly isolated and 5 authentic ones, should be an identical species, $B$. coagulans. Smith et al. (13) located $B$. coagulans on the line dividing the species belonging to group 1 and group 2 of Bacillus, because the sporangia of $B$. coagulans sometimes swelled with oval spores. Although four strains of $B$. coagulans having slightly swollen sporangia were compared with the other seven strains of $B$. coagulans showing unswollen sporangia, we could not detect any relationship between the shape of sporangia and the values of DNA homology.

Identity of the species $B$. cereus and $B$. thuringiensis. Since close similarity has been observed in morphological and physiological characteristics (6), fatty acid composition of cells $(7,8)$, and the flagellar antigen $(9)$ between some strains of $B$. thuringiensis and $B$. cereus, it has been claimed that these two species should be included in the same species. However, in insect pathology, strains of $B$. thuringiensis are distinguishable from those of $B$. cereus by their ability to produce crystalline parasporal bodies (8). According to the data of DNA competition studies by Somerville and Jones (14), closely related DNA homology between the strains of these two species was suggested. To investigate the above possibility, we tested DNA homologies between four strains of $B$. cereus and three strains of $B$. thuringiensis by using $B$. cereus strain $\mathrm{T}$ as the standard (Table 4). All of the test strains were of authentic origin. All of the strains of $B$. cereus showed $79 \%$ or higher homology to the standard strain, and the homologies of the three strains of $B$. thuringiensis to the same standard were 54 to $80 \%$. Since these values are significantly high, it may be concluded that these two species, $B$. cereus and $B$. thuringiensis, should be the same single species, e.g., $B$. cereus, and the designation of $B$. thuringiensis should be regarded as one variant of $B$. cereus. On the other hand, it was clear that these strains are distinct from the other species of Bacillus so far tested as the DNA homology indexes were low (1 to $5 \%$ ) (see Table 5).

Two groups of $B$. sphaericus. B. sphaericus is characterized by its spherical spore shape (5, $6,13)$. Among the five strains of $B$. sphaericus so far tested, the DNA homology indexes fell into two groups, one showing higher $(98 \%)$ and the other showing lower (18\%) homology to the DNA prepared from strain ATCC 14577, whereas it was clear that the strains of both the groups were distinct from the other species of Bacillus so far examined (Table 5). Since the relationship of these two groups in $B$. sphaericus
TABLE 4. DNA homologies among the strains of $B$. cereus and $B$. thuringiensis ${ }^{a}$

\begin{tabular}{lc}
\hline \multicolumn{1}{c}{ Strain } & $\begin{array}{c}\text { Homology to } B . \\
\text { cereus T }(\%)\end{array}$ \\
\hline B. cereus & 100 \\
T & 79 \\
ATCC 14579 & 88 \\
IAM 1229 & 80 \\
ATCC 13824 & \\
B. thuringiensis & 54 \\
subsp. aizawai & 59 \\
subsp. kurstaki & 80 \\
subsp. thuringiensis & \\
\hline
\end{tabular}

a The homology index is expressed as percentage of input DNA bound to a certain disk DNA relative to the homologous reaction.

is similar to that of $B$. subtilis and B. amyloliquefaciens, for which the DNA homology index was about $20 \%(12)$, it is possible that the strains of these two groups are different species, as they are more similar to each other than to the other species. However, no criteria have been suggested to separate these two groups in terms of the conventional taxonomic method.

Interspecific DNA homology of the genus Bacillus. To determine the DNA homologies among the wide variety of species in the genus Bacillus described above, ${ }^{3} \mathrm{H}$-labeled input DNAs were prepared from seven authentic standard strains, $B$. subtilis $168, B$. pumilus IFO 12092 , B. firmus ATCC 14575, B. coagulans ATCC $7050, B$. cereus $\mathrm{T}, \boldsymbol{B}$. circulans ATCC 4513, and $B$. sphaericus ATCC 14577, and they were hybridized with the disk DNAs from 34 strains belonging to 16 species. No significant homology was indicated between the different species of Bacillus, except for a group of species consisting of $B$. subtilis, $B$. amyloliquefaciens, $B$. licheniformis, and $B$. pumilus and for another group, i.e., $B$. cereus and $B$. thuringiensis. However, most of the DNA homologies of the 16 species of Bacillus were higher ( $2 \%$ or more) than those of $E$. coli K-12 (1\%) (Table 5).

In a previous study (12), we observed that $B$. subtilis, $B$. amyloliquefaciens, and $B$. licheniformis are more closely related to each other than to the other species of Bacillus by the study of interspecific hybridization of DNA and genetic transformation of antibiotic resistance traits. It was also suggested that $B$. pumilus IFO 12110 , the only strain of $B$. pumilus that we tested in the previous study, has somewhat higher homology to the DNAs from $B$. subtilis 168 and W23, B. amyloliquefaciens KA-63, and $B$. licheniformis IFO 12107, as we observed homology values of 7 to $9 \%$. This was confirmed with the other four strains of $B$. pumilus, and we observed a homology index of $6 \%$ to input 
TABLE 5. DNA homologies among various strains of Bacillus ${ }^{a}$

\begin{tabular}{|c|c|c|c|c|c|c|c|}
\hline \multirow[b]{2}{*}{ Disk DNA } & \multicolumn{7}{|c|}{ Input DNA homology (\%) of: } \\
\hline & $\begin{array}{c}\text { B. sub- } \\
\text { tilis } \\
168\end{array}$ & $\begin{array}{l}\text { B. pumi- } \\
\text { lus } \\
\text { IFO } \\
12092\end{array}$ & $\begin{array}{c}\text { B. firmus } \\
\text { ATCC } \\
14575\end{array}$ & $\begin{array}{c}\text { B. coa- } \\
\text { gulans } \\
\text { ATCC } \\
7050\end{array}$ & $\begin{array}{l}\text { B. cer- } \\
\text { eus } \\
\mathrm{T}\end{array}$ & $\begin{array}{c}\text { B. circu- } \\
\text { lans } \\
\text { ATCC } \\
4513\end{array}$ & $\begin{array}{c}\text { B. } \\
\text { sphaeri- } \\
\text { cus } \\
\text { ATCC } \\
14577\end{array}$ \\
\hline \multicolumn{8}{|l|}{ B. subtilis } \\
\hline 168 & 100 & 8 & 4 & 4 & 5 & 3 & 2 \\
\hline subsp. niger OUT 8110 & 73 & 8 & 4 & $-b$ & 4 & 4 & 2 \\
\hline B. amyloliquefaciens KA-63 & 19 & 8 & 4 & - & 4 & 4 & 3 \\
\hline B. licheniformis IFO 12107 & 9 & 8 & 4 & 4 & - & 4 & 2 \\
\hline \multicolumn{8}{|l|}{ B. pumilus } \\
\hline IFO 12086 & 6 & 80 & 4 & - & 4 & 4 & 4 \\
\hline IFO 12092 & 6 & 100 & 4 & - & 4 & 4 & 3 \\
\hline IFO 12094 & 6 & 97 & 4 & - & 5 & 4 & 3 \\
\hline IFO 12101 & 6 & 76 & 4 & 3 & 5 & 5 & 3 \\
\hline \multicolumn{8}{|l|}{ B. firmus } \\
\hline ÁTCC 14575 & 3 & 4 & 100 & 2 & 4 & 5 & 3 \\
\hline IFO 3330 & 4 & 3 & 101 & - & 4 & 5 & 3 \\
\hline B. lentus ATCC 10840 & 2 & 2 & 3 & 2 & 4 & 3 & 3 \\
\hline \multicolumn{8}{|l|}{ B. coagulans } \\
\hline ATCC 7050 & 3 & 4 & 4 & 100 & 4 & 4 & 2 \\
\hline IFO 3887 & 4 & - & - & 113 & - & - & - \\
\hline IFO 12583 & 4 & - & - & 99 & - & - & - \\
\hline $\mathrm{C} 2$ & 4 & - & - & 76 & - & - & - \\
\hline B. megaterium IAM 1030 & 3 & 4 & 3 & - & 5 & 4 & 3 \\
\hline \multicolumn{8}{|l|}{ B. cereus } \\
\hline $\mathrm{T}$ & - & 2 & 2 & - & 100 & - & - \\
\hline ATCC 14579 & 1 & - & 2 & - & 79 & 1 & 3 \\
\hline \multicolumn{8}{|l|}{ B. thuringiensis } \\
\hline subsp. kurstaki & 2 & - & 2 & - & 59 & 3 & 3 \\
\hline subsp. thuringiensis & - & 2 & 2 & - & 80 & - & - \\
\hline \multicolumn{8}{|l|}{ B. circulans } \\
\hline ATCC 4513 & 3 & 4 & 4 & 2 & 5 & 100 & 3 \\
\hline IFO 3329 & 2 & 3 & 2 & - & 3 & 2 & 2 \\
\hline IFO 3342 & 2 & 2 & 2 & - & 3 & 2 & 2 \\
\hline B. polymyxa ATCC 842 & 2 & 2 & 2 & 2 & - & 2 & 2 \\
\hline B. laterosporus ATCC 64 & 2 & 3 & 2 & 2 & 3 & 3 & 2 \\
\hline \multicolumn{8}{|l|}{ B. brevis } \\
\hline IFO 3864 & 1 & 1 & 1 & - & - & 1 & 1 \\
\hline IFO 12333 & 2 & 2 & 2 & - & 2 & 2 & 2 \\
\hline \multicolumn{8}{|l|}{ B. sphaericus } \\
\hline ATCC 14577 & 3 & 3 & - & 2 & - & 3 & 100 \\
\hline IFO 3341 & - & 3 & - & - & 5 & - & 18 \\
\hline IFO 3525 & - & 3 & 2 & - & - & 4 & 98 \\
\hline IFO 3526 & 2 & 3 & 3 & - & 5 & 3 & 18 \\
\hline IFO 3528 & - & 3 & - & - & - & - & 18 \\
\hline $\begin{array}{l}\text { B. pantothenticus ATCC } \\
14576\end{array}$ & 3 & 4 & 3 & 2 & 4 & 4 & 2 \\
\hline Escherichia coli $\mathrm{K}-12$ & 1 & 1 & 1 & 1 & 1 & 1 & 1 \\
\hline
\end{tabular}

${ }^{a}$ The homology index is expressed as percentage of input DNA bound to a certain disk DNA relative to the homologous reaction.

${ }^{b}-$, Not tested.

DNA from $B$. subtilis 168 . Conversely, disk DNAs prepared from two strains of $B$. subtilis, 168 and OUT 8110, from $B$. amyloliquefaciens KA-63, and from $B$. licheniformis IFO 12107 showed a homology index of $8 \%$ to the ${ }^{3} \mathrm{H}$-labeled input DNA from $B$. pumilus IFO 12092
(Table 5). These results strongly suggest that $B$. subtilis, $B$. amyloliquefaciens, $B$. licheniformis, and $B$. pumilus are distinctive species but that they are more closely related to each other than to the other 12 species.

$B$. lentus was originally distinguished from $B$. 
firmus by the production of a distinct titratable alkalinity in urea broth and by a lack of action on gelatin and casein $(4,13)$. In the last edition of Bergey's Manual (8th ed.; 5), this species was considered to be a homologous species with $B$. firmus and was rejected from the type species of Bacillus. However, the DNA homology index of B. lentus ATCC 10840 to B. firmus ATCC 14575 was significantly low (3\%) (Table 5). This result indicates that the species of $B$. lentus was independent from $B$. firmus. Further investigation of the DNA homology and taxonomic significance with more test strains will be interesting.

$B$. pantothenticus was also rejected from the type species of Bacillus in Bergey's Manual, 8th ed. $(5,6,13)$, because of its physiological similarity to $B$. circulans. However, DNA from $B$. pantothenticus ATCC 14576 showed a low homology index (4\%) to that of $B$. circulans strain ATCC 4513 (Table 5). These data clearly indicate that these two strains should belong to separate species. Since the other two strains of $B$. circulans, IFO 3329 and IFO 3342 , also showed low homology indexes $(2 \%)$ to $B$. circulans ATCC 4513 , it was strongly suggested that there is significant heterogeneity of strains in $B$. circulans, and further intensive study of this species is necessary.

\section{DISCUSSION}

In a previous paper (12), we demonstrated two different groups of strains in $B$. subtilis and claimed that $B$. subtilis subsp. amyloliquefa- ciens should be separated from $B$. subtilis. The DNA homology between two strains belonging to an identical group was $59 \%$ or more, whereas that between two strains belonging to the different groups was 15 to $36 \%$, although these two groups of strains could not be distinguished by the conventional taxonomic procedure. No transformation of the auxotrophic markers in the Marburg strain of $B$. subtilis with DNA prepared from the strains of $B$. amyloliquefaciens has been detected. With the same DNA preparation, the antibiotic resistance markers have been transformed to the Marburg strain at a low frequency and also with DNA prepared from some strains of $B$. licheniformis and $B$. pumilus. From the above observation, we tentatively formulated a definition of a species: a species is a group of strains of which the intraspecific DNA homology indexes are higher than $50 \%$. According to this definition, the strains of $B$. pumilus tested in the present study and those of $B$. coagulans were in good accord with the species nomenclature by the conventional taxonomic method, whereas significant heterogeneities were suggested in strains of $B$. circulans and those of $B$. sphaericus. On the other hand, $B$. cereus and $B$. thuringiensis should be grouped into the same nomenclatural species, since the DNA homology indexes ranged from 54 to $88 \%$ for four $B$. cereus and three $B$. thuringiensis strains tested (Table 4), although these two species are distinct with respect to insect pathology. Similarly, difficulty was also encountered in the

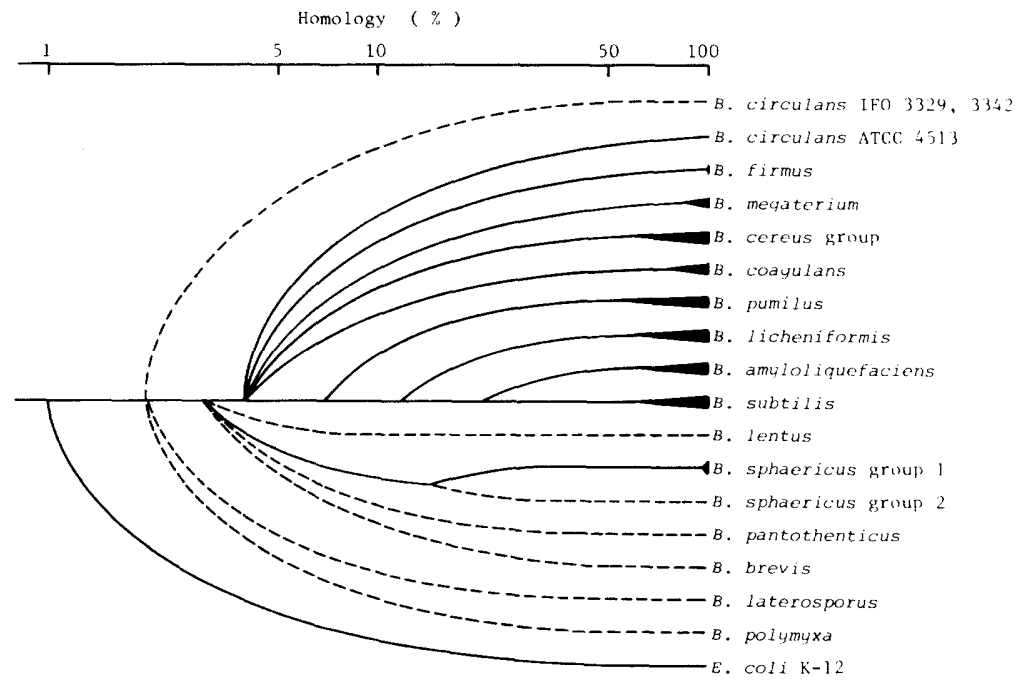

FIG. 1. Diagrammatic representation of the relation between 16 species of Bacillus. Each branching point represents the average percent homology between each combination of two species from Table 5 and the results of a previous report (12). For the species connection, the solid lines were drawn with the average values of the direct reciprocal data by using the input ${ }^{3} \mathrm{H}$-labeled DNA and disk DNA for both the reference strains, whereas each broken line was drawn with data from the combination of respective disk DNA with an input ${ }^{3} \mathrm{H}$-labeled DNA prepared from the reference strain. 
classification of Enterobacteriaceae. Although the genera Escherichia, Shigella, and Salmonella were separated with regard to their pathogenic potencies, the facts of high DNA homology (1-3) and occurrence of genetic recombination among them suggested that they should be classified into one genus or into one species. To solve the above difficulty, further intensive genetic and molecular analysis of the microorganisms is required.

Since the DNA homologies of 16 species including $B$. amyloliquefaciens were low, except for a group of species consisting of $B$. subtilis, $B$. amyloliquefaciens, $B$. licheniformis, and $B$. pumilus, and the two strain-groups in $B$. sphaericus, the genus Bacillus consists of a wide range of divergent species. No distinctive relation was observed by the study of DNA homology with respect to the strain classification of groups 1,2 , and 3 by the morphological characteristics of sporangia and spores. The relationships deduced from the DNA homology data are summarized in a dendrogram (Fig. 1), in which the DNA homology indexes between two species are represented by the branching point on the scale, and the extent of the intraspecific divergence of DNA homogeneity so far observed is shown by the black wedge-shape.

\section{ACKNOWLEDGMENTS}

We thank K. Aizawa of Kyushu University, H. O. Halvorson of Brandeis University, and the Institute for Fermentation, Osaka, for their generous gifts of the authentic strains used. We wish to thank N. Takada of our department for his taxonomic advice. We also thank K. Sato of Meiji Seika Co., Ltd., for his gift of penicillin G.

\section{REPRINT REQUESTS}

Address reprint requests to: Dr. Yasuji Oshima, Department of Fermentation Technology, Osaka University, Yamadakami, Suita-shi, Osaka 565, Japan.

\section{ADDENDUM IN PROOF}

We were recently informed by $T$. Kaneko, $R$. Nozaki, and K. Aizawa that they observed close similarities in the $\mathrm{G}+\mathrm{C}$ contents and DNA-DNA hybridizations of Bacillus anthracis, B. cereus, and B. thuringiensis (Microbiol. Immunol. [Tokyo], in press; for offprints contact: T. Kaneko, The Institute of Physical and Chemical Research, Wako-shi, Saitama 351, Japan).

\section{LITERATURE CITED}

1. Brenner, D. J., G. R. Fanning, K. E. Johnson, R. V. Citarella, and S. Falkow. 1969. Polynucleotide sequence relationships among members of Enterobacteriaceae. J. Bacteriol. 98:637-650.

2. Brenner, D. J., G. R. Fanning, F. J. Skerman, and S. Falkow. 1972. Polynucleotide sequence divergence among strains of Escherichia coli and closely related organisms. J. Bacteriol. 109:953-965.

3. Crosa, J. H., D. J. Brenner, W. H. Ewing, and S. Falkow. 1973. Molecular relationships among the salmonelleae. J. Bacteriol. 115:307-315.

4. Gibson, T. 1935. The urea-decomposing microflora of soils. I. Description and classification of the organisms. Zentralbl. Bakteriol. Parasitenkd. Infektionskr. Hyg. Abt. 2 92:364-380.

5. Gibson, T., and R. E. Gordon. 1974. Endospore-forming rods and cocci. Family I. Bacillaceae, genus I. Bacillus Cohn, p. 529-550. In R. E. Buchanan and N. E. Gibbons (ed.), Bergey's manual of determinative bacteriology, 8th ed. The Williams \& Wilkins Co., Baltimore.

6. Gordon, R. E., W. C. Haynes, and C. H.-N. Pang. 1973. The genus Bacillus. Agricultural handbook no. 427. U.S. Department of Agriculture, Washington, D.C.

7. Kaneda, T. 1967. Fatty acids in the genus Bacillus. I. Isoand anteiso-fatty acids as characteristic constituents of lipids in 10 species. J. Bacteriol. 93:894-903.

8. Kaneda, T. 1968. Fatty acids in the genus Bacillus. II Similarity in the fatty acid compositions of Bacillus thuringiensis, Bacillus anthracis, and Bacillus cereus. J. Bacteriol. 95:2210-2216.

9. Krieg, A. 1969. In vitro determination of Bacillus thuringiensis, Bacillus cereus, and related bacilli. J. Invertebr. Pathol. 15:313-320.

10. Lovett, P. S., and F. E. Young. 1969. Identification of Bacillus subtilis NRRL B-3275 as a strain of Bacillus pumilus. J. Bacteriol. 100:658-661.

11. Marmur, J. 1961. A procedure for the isolation of deoxyribonucleic acid from micro-organisms. J. Mol. Biol. 3:208-218.

12. Seki, T., T. Oshima, and Y. Oshima. 1975. Taxonomic study of Bacillus by deoxyribonucleic acid-deoxyribonucleic acid hybridization and interspecific transformation. Int. J. Syst. Bacteriol. 25:258-270.

13. Smith, N. R., R. E. Gordon, and F. E. Clark. 1952. Aerobic sporeforming bacteria. Agricultural monograph no. 16. U.S. Department of Agriculture, Washington D.C.

14. Somerville, H. J., and M. L. Jones. 1972. DNA competition studies within the Bacillus cereus group of bacilli. J. Gen. Microbiol. 73:257-265.

15. Spizizen, J. 1958. Transformation of biochemically deficient strains of Bacillus subtilis by deoxynucleate. Proc. Natl. Acad. Sci. U.S.A. 44:1072-1078. 